\title{
Predictors of Vesicoureteral Reflux in the Pretransplant Evaluation of Patients with End-Stage Renal Disease
}

\author{
[D] Ergün Parmaksız, (1) Meral Meşe, (1) Zuhal Doğu, (1) Zerrin Bicik Bahçebaşı
}

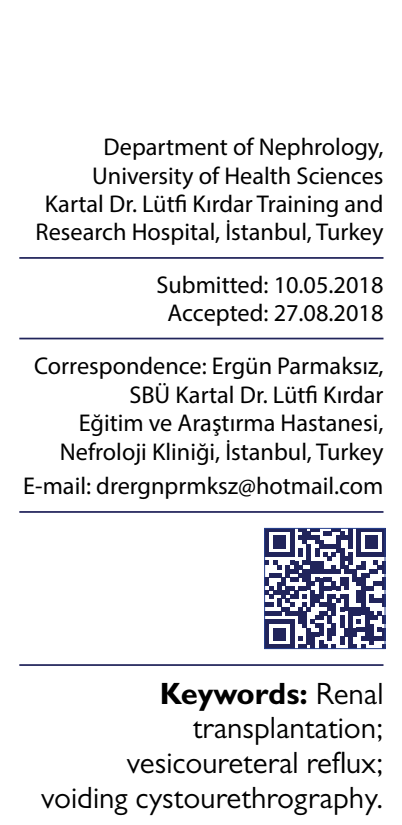

\begin{abstract}
Objective: Voiding cystourethrography (VCUG) is widely performed in the pretransplant evaluation of patients with a history of urological disorders to detect vesicoureteral reflux (VUR). The aim of this study was to evaluate the relationship between the primary etiology of end-stage renal disease (ESRD) and the prevalence of VUR, thereby determining the necessity for VCUG in pretransplant patients.
\end{abstract}

Methods: A total of 319 pretransplant cases that underwent VCUG were retrospectively reviewed.

Results: VCUG revealed VUR in 53 (16.6\%) cases. VUR was left-sided in 21 (4I.2\%), rightsided in $18(35.3 \%)$, and bilateral in $12(3.8 \%)$, and grade 1 in $10(19.6 \%)$, grade 2 in 19 (37.3\%), grade 3 in 20 (39.2\%), and grade 4 in 2 (3.9\%). The etiology of ESRD was hypertension in $125(39.2 \%)$, diabetes mellitus (DM) in 46 (14.4\%), polycystic kidney disease (PKD) in 21 (6.6\%), amyloidosis in 16 (5\%), VUR in II (3.4\%), and glomerulonephritis (GN) in II (3.4\%). The incidence of VUR was significantly higher in female patients. Hypertension, DM, PKD, amyloidosis, and GN were not found to predict VUR. The rate of abnormal VCUG findings was similar in cases with secondary and idiopathic ESRD.

Conclusion: The findings demonstrate that only sex was a predictor of VUR in pretransplant cases. The presence of VUR was not related to any cause of ESRD; therefore, VCUG is not needed in all cases as a part of pretransplant evaluation.

\section{INTRODUCTION}

Vesicoureteral reflux (VUR) is a congenital or acquired abnormality of the urinary tract. It is diagnosed in $30 \%-40 \%$ of children presenting with urinary tract infections (UTIs), predominantly girls. ${ }^{\left[{ }^{[l]}\right.}$

VUR is classified by radiological evaluation on voiding cystourethrography (VCUG) into five grades as defined by the International Reflux Study in Children. ${ }^{[2]}$ Renal injury is the combination of VUR and repeated UTI, which is also called acquired reflux nephropathy ( $R N)$. $R N$ is diagnosed using technetium $99 \mathrm{~m}$ dimercaptosuccinic acid renal scanning as defects in the renal outline. ${ }^{[3]}$ The presence of VUR increases the risk of upper UTI, and in case of bilaterally, it can cause renal injury, leading to scarring of the kidney termed RN. RN may present as hypertension or chronic kidney disease (CKD). Some patients have proteinuria as a result of secondary focal segmental glomerulosclerosis (FSGS). Renal scarring is responsible for $5 \%-10 \%$ of endstage renal disease (ESRD) in adult patients. ${ }^{[4,5]}$ The loss of nephron is associated with hyperfiltration and hypertension that result in proteinuria and progressive loss of renal function that leads to the development of FSGS. The clinical manifestations of RN are varied and may include complicated UTI, hypertension, ${ }^{[6]}$ proteinuria, ${ }^{[7]}$ an increased risk of renal calculi, and various manifestations of CKD. ${ }^{[8]}$

VUR is most commonly found after repeated UTI. The prevalence of VUR is higher in younger patients and decreases with age; $5 \%$ of sexually active women with UTI have VUR. 
Screening for genitourinary disorders before renal transplantation is indicated in those with a history or renal ultrasonography suggestive of urinary obstruction, especially in whom urological problems are a major cause of ESRD. Traditional management includes prompt treatment of UTI or surgical correction of the VUR in those who are unfit for medical management.

VCUG is widely performed to detect VUR in the pretransplant evaluation of patients with a history of urological disorders. We aimed to evaluate the relationship between primary etiology of ESRD and prevalence of VUR, thereby finding the necessity of VCUG in pretransplant patients.

\section{MATERIAL AND METHODS}

We retrospectively examined the files of renal transplant candidates applying to our transplantation clinic between January 2008 and January 2014. All patients who underwent VCUG as a part of pretransplant evaluation were included in the study. Demographic data and known etiologies of ESRD were recorded. None of the subjects had a history of surgery for VUR. We examined the VCUGs of 319 patients who underwent assessment for renal transplantation in our center. VCUG had been performed after the bladder was emptied. A $150 \mathrm{cc}$ of contrast media was infused through a urethral catheter under fluoroscopy until the bladder became full. During the procedure, any vesicoureteral reflux was noted. We tried to find an abnormal VCUG finding including any grade of VUR (I through 4).

Statistical analyses were performed using SPSS for Windows, version 17.0.

Continuous data are expressed as means; discrete data are presented as counts and percentages (\%). Chi-square tests were used for comparison of categorical data. Logistic regression analysis was used to determine the effect of different etiological factors on VUR. A p-value $<0.05$ was considered statistically significant.

\section{RESULTS}

The study population consisted of a total of 319 renal transplant recipient candidates, with $173(54.2 \%)$ male and I 46 (45.8\%) female cases. The mean age of the whole group was 51 (16-70) years.

The etiology of ESRD could be detected in only 197 (61.8\%) cases; 122 cases had ESRD of unknown etiology. The etiological pathologies included hypertension, diabetes mellitus (DM), polycystic kidney disease (PKD), amyloidosis, VUR, and glomerulonephritis (GN). Hypertension was accompanied by DM in 25 cases, amyloidosis in 3 cases, GN in I case, PKD in 3 cases, and VUR in I case. Table I shows the frequencies of these pathologies.
Table I. Frequencies of end-stage renal disease*

\begin{tabular}{|c|c|c|}
\hline Etiology of end-stage renal disease & $\mathbf{n}$ & $\%$ \\
\hline Hypertension & 125 & 39.2 \\
\hline Diabetes mellitus & 46 & 14.4 \\
\hline Polycystic kidney disease & 21 & 6.6 \\
\hline Amyloidosis & 16 & 5 \\
\hline Vesicoureteral reflux & II & 3.4 \\
\hline Glomerulonephritis & II & 3.4 \\
\hline Unknown & 122 & 38.2 \\
\hline
\end{tabular}

Table 2. Frequency of vesicoureteral reflux in each group*

\begin{tabular}{lccc}
\hline Etiology of ESRD & n & VUR (+) (n) & P value \\
\hline Hypertension & 125 & 17 & 0.24 \\
Diabetes mellitus & 46 & 6 & 0.48 \\
Polycystic kidney disease & 21 & 1 & 0.13 \\
Amyloidosis & 16 & 0 & 0.06 \\
Glomerulonephritis & 11 & 3 & 0.33 \\
Unknown & 122 & 20 & 0.93 \\
\hline
\end{tabular}

*25 cases had hypertension+diabetes mellitus, 3 cases had hypertension+amyloidosis, 3 cases had hypertension+polycystic kidney disease, I case had hypertension+glomerulonephritis, and I case had hypertension+vesicoureteral reflux. ESRD: End-stage renal disease; VUR: Vesicoureteral reflux.

VCUG revealed VUR in $53(16.6 \%)$ cases. VUR was leftsided in $22(41.5 \%)$, right-sided in $19(35.8 \%)$, and bilateral in $12(22.6 \%)$. When classified according to severity, 10 (18.9\%) cases had grade I, $2 \mathrm{I}(39.6 \%)$ cases had grade 2, 20 $(37.7 \%)$ cases had grade 3 , and $2(3.8 \%)$ cases had grade 4 VUR. Of I 46 women, 32 had VUR, whereas of I 73 men, 2 I had abnormal VCUG results. The incidence of VUR was significantly higher in female cases ( $p=0.019$; odds ratio $=0.49$ ).

Table 2 shows the frequency of various comorbidities accompanying VUR. Hypertension, DM, PKD, amyloidosis, and GN could not be found to predict VUR. The rate of abnormal VCUG findings was similar in cases with ESRD of unknown and known etiologies.

When VCUG was consistent with findings of grade 2, 3, and 4 VURs, these patients underwent surgical repair of the condition.

\section{DISCUSSION}

In the current study, we classified pretransplant ESRD based 
on etiologies and evaluated VUR prevalence detected by VCUG. The frequency of VUR was not significantly different in groups with known and unknown etiologies. This result is critically important to denote that VCUG is required only for cases with urological abnormalities, but not for the whole group. Detection of VUR as a part of pretransplant evaluation is essential for predicting the outcome and prognosis during the post-transplant period.

The role of pretransplant VCUG in adults has been questioned owing to the low prevalence of abnormal findings. Our study reveals that 53 out of 319 cases with ESRD had VUR; in I I cases, VUR was the etiology for ESRD. Song et al. ${ }^{[9]}$ found VUR in 110 out of 622 (I7.5\%) cases with ESRD, whereas Agarwal et al. ${ }^{[10]}$ demonstrated that 2 I out of 150 (14\%) cases showed VUR on pretransplant work-up. According to Shandera et al.," ${ }^{[1]} 5$ I out of 333 cases had VUR, and 19 had urological abnormalities as the cause of ESRD. Several studies indicate the necessity of VCUG in cases with known urological abnormalities. ${ }^{[1,12]}$ We point out the fact that VUR can be detected with similar prevalence in ESRD due to various known causes. In this regard, it may be thought that VCUG should be indicated for only a selected group of patients in pretransplant work-up. Simsir et al. ${ }^{[13]}$ reported that lower urinary tract evaluation is not recommended in patients with ESRD due to parenchymal disorders.

A previous study showed that VUR was more frequent in males. ${ }^{[14]}$ This finding is contrary to our results, as the female group had higher incidence of VUR than male cases.

There was no statistically significant difference in VUR frequency due to known or unknown etiologies of ESRD, as well as in different groups with various etiologies. Therefore, VCUG should be restricted to a special group of patients. Treatment of VUR contributes to better prognosis in renal transplant patients, and detection carries major importance.

Our findings demonstrate that only sex was found as a predictor of VUR in pretransplant cases. In conclusion, the presence of VUR could not be related to any cause of ESRD; therefore, VCUG is not needed for all cases as a part of pretransplant evaluation.

\section{Ethics Committee Approval}

This was a retrospective study, therefore no ethics committee approval was taken.

Informed Consent

Retrospective study.

Peer-review

Internally peer-reviewed.

Authorship Contributions
Concept: E.P.; Design: E.P.; Data collection \&/or processing: E.P., Z.D.; Analysis and/or interpretation: E.P.; Literature search: M.M.; Writing: E.P.; Critical review: Z.B.B.

Conflict of Interest

None declared.

\section{REFERENCES}

1. Jonhson R, Feehally J. Comprehensive clinical nephrology. 5th ed. Philadelphia: Elsevier; 2015.

2. Lebowitz RL, Olbing H, Parkkulainen KV, Smellie JM, Tamminen-Möbius TE. International system of radiographic grading of vesicoureteric reflux. International Reflux Study in Children. Pediatr Radiol 1985;15:105-9. [CrossRef]

3. Wennerström M, Hansson S, Jodal U, Stokland E. Primary and acquired renal scarring in boys and girls with urinary tract infection. J Pediatr 2000;136:30-4. [CrossRef]

4. Becker GJ, Kincaid-Smith P. Reflux nephropathy: the glomerular lesion and progression of renal failure. Pediatric Nephrology 1993;7:365-9. [CrossRef]

5. el-Khatib MT, Becker GJ, Kincaid-Smith PS. Reflux nephropathy and primary vesicoureteric reflux in adults. QJ Med 1990;77:124153. [CrossRef]

6. Smellie JM, Prescod NP, Shaw PJ, Risdon RA, Bryant TN. Childhood reflux and urinary infection: a follow-up of 10-41 years in 226 adults. Pediatr Nephrol 1998;12:727-36. [CrossRef]

7. Morita M, Yoshiara S, White RH, Raafat F. The glomerular changes in children with reflux nephropathy.J Pathol 1990;162:245-53.

8. Roihuvuo-Leskinen H, Lahdes-Vasama T, Niskanen K, Rönnholm $\mathrm{K}$. The association of adult kidney size with childhood vesicoureteral reflux. Pediatr Nephrol 2013;28:77-82. [CrossRef]

9. Song M, Park J, Kim YH, Han DJ, Song SH, Choo MS, Hong B. Bladder capacity in kidney transplant patients with end-stage renal disease. Int Urol Nephrol 2015;47:101-6. [CrossRef]

10. Agarwal SK, Dash SC, Malhotra KK, Tiwari SC, Mehta SN, Dhawan IK. Incidence of reflux nephropathy (RN) in ESRD and effect of nephrectomy in RN on blood pressure and haematocrit following renal transplantation. J Assoc Physicians India 1989;37:2079.

11. Shandera K, Sago A, Angstadt J, Peretsman S, Jaffers G. An assessment of the need for the voiding cystourethrogram for urologic screening prior to renal transplantation. Clin Transplant 1993;7:299-301.

12. Glazier DB, Whang MI, Geffner SR, Lyman NW, Friedman GS, Viscuso R, Jacobs MG, Mulgaonkar SP. Evaluation of voiding cystourethrography prior to renal transplantation. Transplantation 1996;62:1762-5. [CrossRef]

13. Simsir A, Dheir H, Mammadow R, Hoscoskun C, Toz H, Ok E, et al. Evaluation of the lower urinary tract before renal transplantation: to which patients? How? Open Journal of Urology 2012;2:127-30.

14. Sakhuja V, Muthukumar T, Sud K, Gupta A, Kohli HS, Jha V, et al. Vesicoureteric reflux and reflux nephropathy as seen at a tertiary care adult nephrology service in India--an analysis of 86 patients. Ren Fail 2003;25:173-81. [CrossRef] 


\section{Renal Transplantasyon Öncesi Değerlendirmede Vezikoüreteral Reflünün Belirteçleri}

Amaç: Voiding sistoüretrografi (VSUG) ürolojik hastalık öyküsü olan olguların transplantasyon öncesi vezikoüretral reflü (VUR) açısından değerlendirilmesinde sıklıkla kullanılır.

Gereç ve Yöntem: Son dönem böbrek hastalığının (SDBH) etiyolojisi ile VUR prevalansı ilişkisini ve VSUG gerekliliğini değerlendirmeyi amaçladık. Transplantasyon öncesi VSUG uygulanan 319 hasta geriye dönük olarak değerlendirildi.

Bulgular: Voiding sistoüretrografi ile 53 (\%|6.6) olguda VUR saptandı; 2 I (\%4I.2) sol taraflı, I8 (\%35.3) sağ taraflı, I2 (\%3.8)iki taraflı; I0 (\% 19.6) grade I, I 9 (\%37.3) grade 2, 20 (\%39.2) grade 3 ve 2 (\%3.9) grade 4 idi. SDBH sebebi 125 (\%39.2) olguda hipertansiyon, 46 (\% I4.4) olguda, polya DM, 2 I (\%6.6) kistik böbrek hastalı̆ı, 16 (\%5) olguda amiloidoz, II (\%3.4) olguda VUR ve II (\%3.4) olguda glomerulonefrit idi. VUR sıklığı kadınlarda anlamlı olarak daha fazla bulundu. Hipertansiyon, DM, polikistik böbrek hastalığı, amiloidoz ve glomerulonefrit VUR belirteci olarak bulunmadı. Anormal VSUG bulgusu sıklı̆ı sekonder ve idyopatik SDBH olgularında benzer bulundu.

Sonuç: Çalışmamız, cinsiyetin VUR için anlamlı bir belirteç olduğu sonucunu ortaya koymuştur. VUR varlığı ile SDBH etiyolojisi arasında ilişki bulunmadı. Bu nedenle transplantasyon öncesi değerlendirmede VSUG yapılmasının gerekli olmadığı kanaatindeyiz.

Anahtar Sözcükler: Böbrek nakli; vezikoüreteral reflü; voiding sistoüreterografi. 